\title{
Dissolved noble gases and stable isotopes as tracers of preferential fluid flow along faults in the Lower Rhine Embayment, Germany
}

\author{
L. P. Gumm ${ }^{1}$ - V. F. Bense ${ }^{2}$ P. F. Dennis ${ }^{1}$ - K. M. Hiscock ${ }^{1}$ - N. Cremer ${ }^{3} \cdot$ S. Simon $^{3}$
}

Received: 6 March 2015 / Accepted: 30 September 2015 / Published online: 19 October 2015

(C) The Author(s) 2015. This article is published with open access at Springerlink.com

\begin{abstract}
Groundwater in shallow unconsolidated sedimentary aquifers close to the Bornheim fault in the Lower Rhine Embayment (LRE), Germany, has relatively low $\delta^{2} \mathrm{H}$ and $\delta^{18} \mathrm{O}$ values in comparison to regional modern groundwater recharge, and ${ }^{4} \mathrm{He}$ concentrations up to $1.7 \times 10^{-4} \mathrm{~cm}^{3}$ (STP) $\mathrm{g}^{-1} \pm 2.2 \%$ which is approximately four orders of magnitude higher than expected due to solubility equilibrium with the atmosphere. Groundwater age dating based on estimated in situ production and terrigenic flux of helium provides a groundwater residence time of $\sim 10^{7}$ years. Although fluid exchange between the deep basal aquifer system and the upper aquifer layers is generally impeded by confining clay layers and lignite, this study's geochemical data suggest, for the first time, that deep circulating fluids penetrate shallow aquifers in the locality of fault zones, implying that sub-vertical fluid flow occurs along faults in the LRE. However, large hydraulic-head gradients observed across many faults suggest that they act as barriers to lateral groundwater flow. Therefore, the geochemical data reported here also substantiate a conduitbarrier model of fault-zone hydrogeology in unconsolidated sedimentary deposits, as well as corroborating the concept that faults in unconsolidated aquifer systems can act as loci for hydraulic connectivity between deep and shallow aquifers. The implications of fluid flow along faults in sedimentary
\end{abstract}

V. F. Bense

victor.bense@wur.nl

1 School of Environmental Sciences, University of East Anglia, Norwich Research Park, Norwich NR4 7TJ, UK

2 Hydrology and Quantitative Water Management Group, Department of Environmental Sciences, Wageningen University, 6708 PB Wageningen, The Netherlands

3 Erftverband, Am Erftverband 6, 50126 Bergheim, Germany basins worldwide are far reaching and of particular concern for carbon capture and storage (CCS) programmes, impacts of deep shale gas recovery for shallow groundwater aquifers, and nuclear waste storage sites where fault zones could act as potential leakage pathways for hazardous fluids.

Keywords Fault zone hydrogeology · Noble gases · Unconsolidated sedimentary aquifers · Germany · Hydrochemistry

\section{Introduction}

Large hydraulic head gradients observed across fault zones in unconsolidated sedimentary aquifers suggest that they often form effective barriers to lateral groundwater flow (Rawling et al. 2001; Bense and Van Balen 2004; Mayer et al. 2007; Bense et al. 2013). These barriers are created by the juxtaposition of aquifer-confining units such as clay beds with aquifer media at the location of the fault (Mailloux et al. 1999) and/or fault zone deformation processes such as cataclasis (Fulljames et al. 1997), diagenesis (Chan et al. 2000; Dewhurst and Jones 2003) and clay smearing (Lehner and Pilaar 1997; Bense et al. 2003; Egholm et al. 2008), which reduce the permeability of the fault zone itself. The role of faults as barriers to groundwater movement has been widely described in the literature but much less documented is the ability of faults to simultaneously act as conduits for sub-vertical flow along the fault (Roberts et al. 1996; Wiprut and Zoback 2000; Bense and Person 2006). Hydraulic head observations are typically not sufficient to infer the magnitude and direction of fluid flow along faults, usually due to the sparse distribution of observation boreholes. However, the application of noble gas tracers has been particularly useful in characterizing fluid flow associated with faults as conduit-barrier structures in both deep 
(Wiersberg and Erzinger 2011) and shallow (Kulongoski et al. 2003,2005 ) settings. In general, the potential for fluid migration along faults is an important consideration for water resources management as well as proposed carbon capture and storage (CCS) programmes (Shipton et al. 2004; Bickle et al. 2007; Gilfillan et al. 2009), shale gas recovery from deep hydrological environments and its implications for shallow groundwater quality (Cassiat et al. 2013), and nuclear waste storage sites (Flint et al. 2001; Dublyansky and Spötl 2010) where faults could act as potential leakage pathways for hazardous fluids.

Geochemical tracers are useful tools for investigating the origin and residence time of deep circulating fluids in aquifer systems worldwide (Kipfer et al. 2002; Lippmann et al. 2005; $\mathrm{Ma}$ et al. 2005). Dissolved noble gases and stable isotopes are particularly useful in studies of aquifer systems that contain pre-Holocene 'palaeo' groundwater (e.g. Vaikmäe et al. 2001) or fluids that have a deep crustal origin such as those observed in the Great Artesian Basin in Australia (Torgersen and Clarke 1985, 1987; Bethke et al. 1999), the Paris Basin in France (Marty et al. 1993, 2003; Castro et al. 1998; Lavastre et al. 2010) and the Witwatersrand Basin in South Africa (Lippmann et al. 2003; Lippmann-Pipke et al. 2011). Dissolved helium has been used extensively for estimating groundwater residence times and tracing the origin of crustal fluids (Torgersen et al. 1992; Ballentine et al. 2002; Gardner et al. 2012). Deep circulating groundwater typically has a radiogenic source of ${ }^{4} \mathrm{He}$ from in situ $\alpha$-decay of U-Th series elements. However, modern groundwater ( $>10$ years) can also exhibit high concentrations of helium which originate from previously trapped reservoirs in the subsurface (Solomon et al. 1996). Helium enrichment in palaeo groundwater is reported in the literature at up to six orders of magnitude higher than expected due to solubility equilibrium with the atmosphere (Andrews and Lee 1979; Castro et al. 1998; Bethke et al. 1999). Terrigenic ${ }^{3,4} \mathrm{He}$ is also significant in deep circulating fluids (Griesshaber et al. 1992; Stute et al. 1992; Ballentine and Burnard 2002; Castro 2004). The ${ }^{3} \mathrm{He} /{ }^{4} \mathrm{He}$ isotope ratio is often used to distinguish between helium of crustal or mantle origin (Oxburgh et al. 1986; Sano et al. 1986; Kulongoski et al. 2003, 2005). However, due to groundwater typically containing helium from several different sources (Solomon et al. 1996; Zhou and Ballentine 2006), helium age dating is usually only used as a technique for estimating groundwater age rather than a precise quantitative tool (Stute et al. 1992; Castro et al. 2000). More recently, however, Torgersen (2010) suggested that it is now possible to determine uncertainty limits associated with crustal fluxes of helium using the increased number of published data sets, thus improving the accuracy of ${ }^{4} \mathrm{He}$ age estimates.

In the unconsolidated sedimentary aquifers of the Lower Rhine Embayment (LRE), Germany, where large hydraulic gradients exist across many faults, suggesting that they act as barriers to groundwater flow, thermal anomalies in aquifer units flanking the Rurrand fault have provided evidence for significant fault-parallel flow (Bense et al. 2008). Here, hydrogeochemical evidence is presented for the upward migration of deep crustal fluids along the Bornheim fault in the LRE.

\section{Study area}

The Lower Rhine Embayment forms part of the Roer Valley Rift System (RVRS), which is the southward extension of the North Sea Basin and part of a Cenozoic mega-rift system that crosses western and central Europe (Ziegler 1994). The German region of the LRE (Fig. 1) covers an area of 3, $800 \mathrm{~km}^{2}$ and contains approximately $1,300 \mathrm{~m}$ of Oligocene to Pleistocene unconsolidated siliciclastic sediments that form a highly complex multi-layered aquifer sequence within six tectonic blocks. The central Erft block is adjacent to the Köln block to the east and the Rur block to the west, whilst the Krefeld and Venlo blocks are situated northeast and northwest, respectively. Each tectonic block consists of 5-15 different aquifers to a depth of $200 \mathrm{~m}$ and the Erft block has as many as 21 separate aquifer units to a depth of approximately $400 \mathrm{~m}$. The LRE is intersected by numerous NW-SE-striking fault zones which have a significant impact on regional groundwater flow patterns (Wallbraun 1992). The formation of the LRE aquifer system began during the Oligocene and is described in great detail by Schäfer et al. (1996). The LRE primarily consists of Oligocene, Miocene and Pliocene marine sediments and the more recent Pleistocene sediments are mainly fluvial deposits derived from the Rhenish Massif to the south (Schäfer et al. 2005). The sediments derived purely from the Rhenish Massif are comprised of gravels that are characterised by having $>90 \%$ quartz material in the coarse gravel fraction and the remaining sediment is made up of quartzite (Boenigk 2002). Highly porous loess soils have formed due to the accumulation of silts, sands and clays, and these overlay the Pleistocene deposits (Kemna 2008). Boenigk (2002) and Kemna (2008) provide detailed mineralogical analyses of the shallow Pleistocene deposits, and Pliocene and lower Pleistocene deposits, respectively. The LRE contains two commercially important lignite seams. The main lignite seam

Fig. 1 a Location of the study area in central Europe. b Hydraulic head distribution within the deeper aquifer units of the Lower Rhine Embayment (LRE), Germany, with spatial reference to the Hambach, Garzweiler and Inden open cast lignite mines. Contour increments vary due to the lower hydraulic head gradients that exist towards the River Rhine. A cone of depression is evident below the Hambach and Garzweiler mines, and the major graben faults frequently act as barriers to lateral groundwater flow. The shallow aquifer system is less impacted by lignite mine dewatering due to confining layers of clay that create relatively shallow perched aquifer conditions in many areas including the Brühl region. The observation boreholes not illustrated on the map are all situated to the north in an area less impacted by lignite mining 

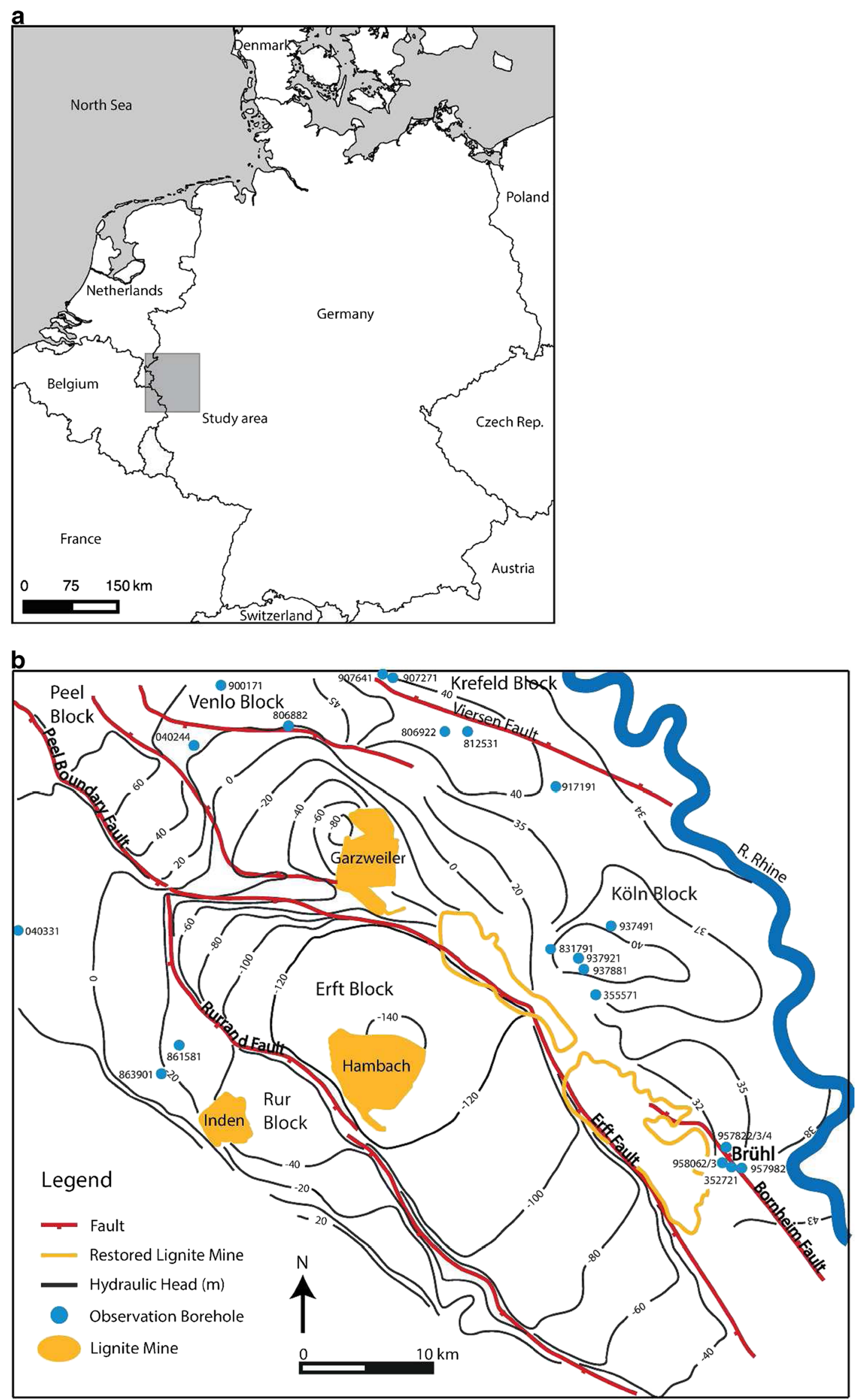


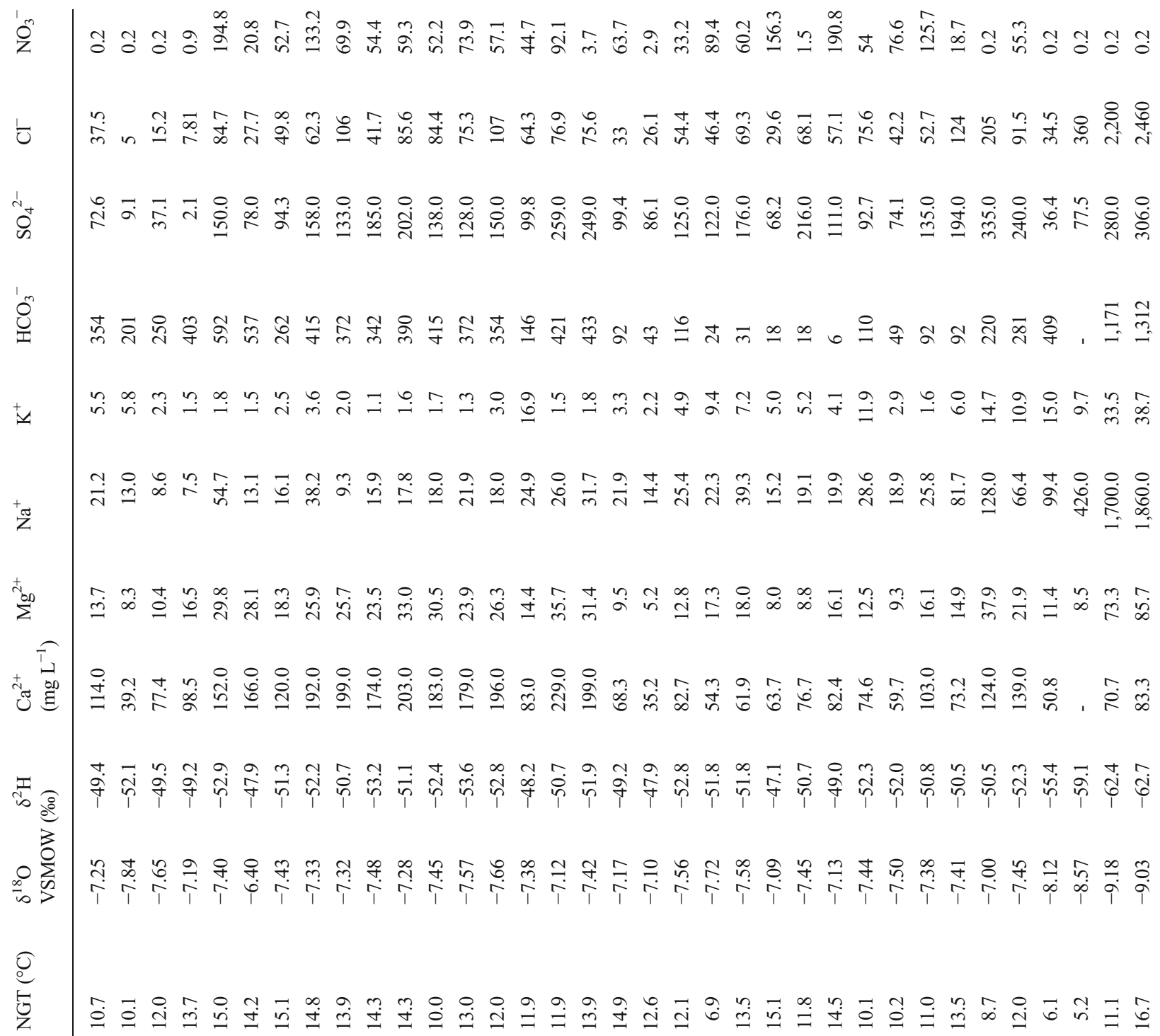

少

$\widetilde{T_{00}}$

\% 웅 $\infty$

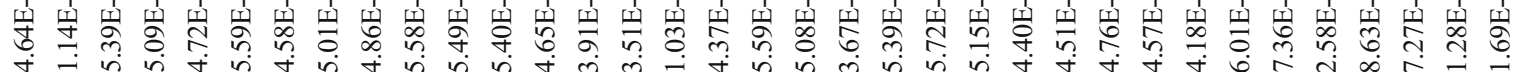

तु 
has a thickness of up to $100 \mathrm{~m}$ and the second 'upper' seam has a thickness of up to $40 \mathrm{~m}$ (Hager 1993). The Miocene lignite deposits of the LRE form one of the largest reserves in Europe with an estimated 55,000 Mt (Hager 1993) with an overburden thickness up to $300 \mathrm{~m}$ (RWE Power AG). The geological structures that underlie the Oligocene aquifers below a depth of 400-800 m are less well known. The oldest sequences identified from borehole records are Palaeozoic. It is known that Carboniferous strata with a total thickness of up to $2,500 \mathrm{~m}$ is underlain by approximately $2,000 \mathrm{~m}$ of clastic sedimentary rocks, limestone and evaporites, and a Devonian sequence of unknown thickness and composition (Geluk et al. 1994). Lower Jurassic sandstone and claystone sequences with a total thickness of up to $1,500 \mathrm{~m}$ are found beneath the Cenozoic sand deposits, and they overlie Permian-Triassic sandstone and conglomerate material (Geluk et al. 1994).

\section{Methods}

Observation boreholes in the LRE were selected at locations in close proximity to faults, and where some historical monitoring records of well head parameters and hydrochemistry were available. Physical limitations of the pumping equipment restricted borehole selection and generally only shallow $(<100 \mathrm{~m})$ aquifer units were sampled. In total 73 piezometers were sampled from 64 observation boreholes during three separate sampling campaigns totalling 23 days in the field. However, only 35 piezometers were successfully sampled for the full range of noble gas, stable isotope and hydrochemical analyses. Boreholes were pumped using a Grundfos MP1 submersible pump and purged to the equivalent of three borehole volumes before groundwater samples were collected. All the observation boreholes were fully cased with filters positioned at specific inflow horizons. The depth of each borehole filter is given in Table 1. Groundwater samples were collected in copper tubes, using clear Portex ${ }^{\mathrm{TM}}$ connective tubing for noble gas ( $\mathrm{He}, \mathrm{Ne}, \mathrm{Ar}, \mathrm{Kr}$ and $\mathrm{Xe}$ ) analyses following the method described by Beyerle et al. (2000) and back pressure was applied to maintain hydrostatic pressure during sampling using a simple ball valve attached to the outflow pipe of the copper tube. Generally, very few gas bubbles were encountered during sampling with the exception of observation borehole 958063 in the Brühl region, which exsolved large quantities of gas during sampling primarily due to a high dissolved $\mathrm{CO}_{2}$ content.

Groundwater samples were also collected and analysed for major ions $\left(\mathrm{Ca}^{2+}, \mathrm{Na}^{+}, \mathrm{Mg}^{2+}, \mathrm{K}^{+}, \mathrm{HCO}_{3}{ }^{-}, \mathrm{SO}_{4}{ }^{2-}, \mathrm{Cl}^{-}\right.$and $\mathrm{NO}_{3}{ }^{-}$) by the Erftverband at their laboratories in Bergheim, Germany using a range of analytical instruments, as well as for water isotopes $\left(\delta^{2} \mathrm{H}\right.$ and $\left.\delta^{18} \mathrm{O}\right)$ at the University of East Anglia (UEA), UK. All Noble gas analyses were conducted at the UEA Stable Isotope Laboratory using a quadrupole mass analyser operated in static mode and isotope dilution mass spectrometry. The analytical procedure is described in detail by Poole et al. (1997). Additionally, a small number of groundwater samples from the Brühl region were analysed for ${ }^{14} \mathrm{C}$ (National Science Foundation grant NSF-EAR 0609809), but pMC was not detected, suggesting that the groundwater age was beyond the dating range of ${ }^{14} \mathrm{C}$.

\section{Results and discussion}

Stable isotope data (Fig. 2a) show that the majority of the observation boreholes sampled in the LRE contain groundwater recharge of meteoric origin. The main cluster of data points shown in Fig. 2a displays a limited range of $\delta^{2} \mathrm{H}$ and $\delta^{18} \mathrm{O}$ values but exhibits a wide range of hydrochemical compositions illustrated by the Durov plot (Fig. 2b) that is typical of modern groundwater from silicate aquifers in which no single mineral dominates weathering reactions (Appelo and Postma 2005). Generally, the isotopic composition of groundwater from the shallow aquifers of the LRE is characteristic of present-day precipitation for this region (IAEA 2006) confirming a 'modern' Holocene recharge. However, seven groundwater samples have relatively low $\delta^{18} \mathrm{O}$ values, whereas two samples have relatively high $\delta^{18} \mathrm{O}$ values and display a typical evaporation trend. The small cluster of samples with $\delta^{18} \mathrm{O}$ values between -9.0 and $-9.2 \%$ originates in a single observation borehole but at slightly different depths. Hydrochemical analysis of these samples show that the ionic composition is $\mathrm{Na}-\mathrm{Cl}-\left(\mathrm{HCO}_{3}\right)$ dominated with $\mathrm{Cl}^{-}$concentration up to $2,460 \mathrm{mg} \mathrm{L}^{-1}$. This groundwater appears to be of meteoric origin as the samples plot on the global meteoric water line (GMWL), implying that recharge must have occurred under cooler climatic conditions than those that predominate today, and therefore strongly suggests the presence of pre-Holocene 'palaeo' groundwater at shallow depth. This groundwater was primarily observed in the Brühl region of the LRE. Previous studies by Schenk $(1981,1982)$ identified the same body of anomalous groundwater near the Bornheim fault in the Brühl region using hydrochemical data but, without the application of geochemical tracers, Schenk (1981, 1982) was unable to establish the age or origin of the fluid. New hydrochemical data suggest that the palaeo groundwater identified in the Brühl region evolved in a hydrogeological setting that was significantly different from the present-day shallow aquifer system. The groundwater appears to have evolved under conditions that led to a low $\mathrm{Ca}^{2+}$ concentration but relatively high $\mathrm{HCO}_{3}{ }^{-}$concentration (Fig. 2c). For groundwater to follow this evolutionary path, it would be necessary to assume a high production rate of $\mathrm{H}^{+}$ions in the aquifer. A mechanism such as the oxidation of pyrite $\left(\mathrm{FeS}_{2}\right)$ 
a

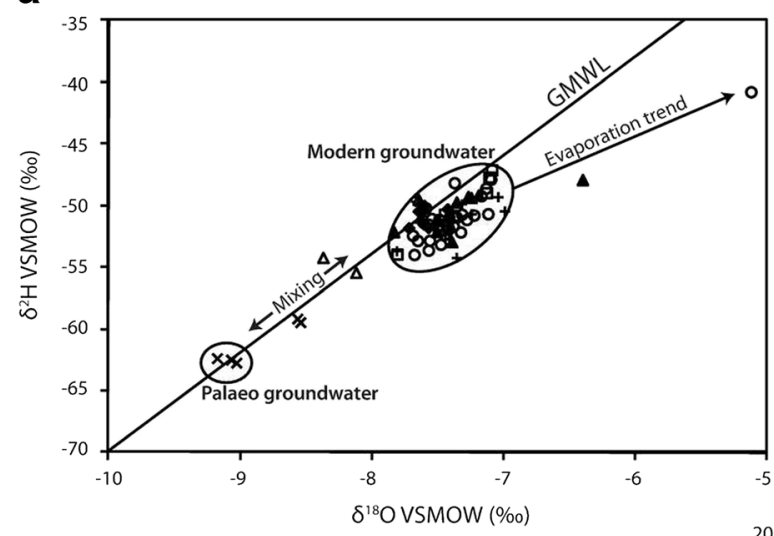

C

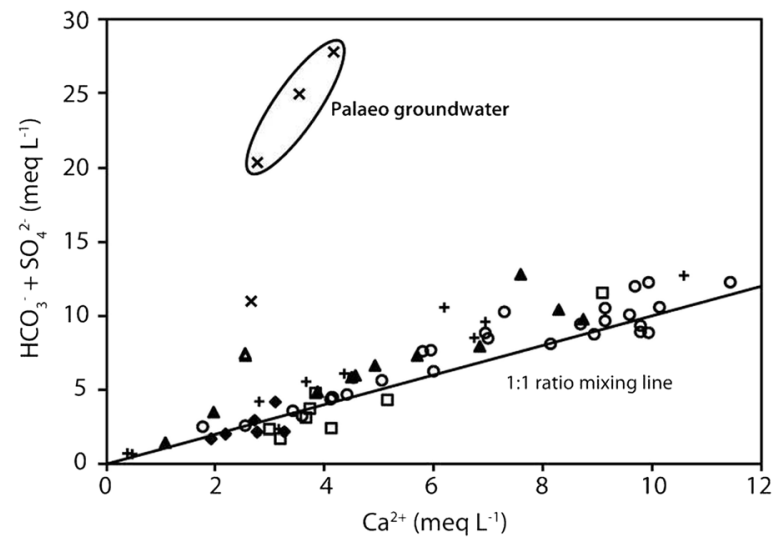

b

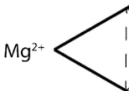

$80-1-1,-$

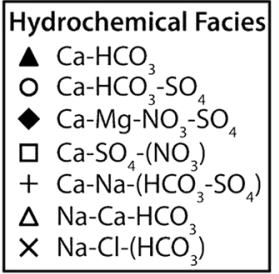

Hydrochemical Facies

$\triangle \mathrm{Na}-\mathrm{Ca}-\mathrm{HCO}$

$\times \mathrm{Na}-\mathrm{Cl}-\left(\mathrm{HCO}_{3}\right)$
Fig. 2 a Isotopic composition of groundwater in the Lower Rhine Embayment (LRE) with reference to the global meteoric water line $(G M W L)$. Palaeo groundwater has relatively low $\delta^{2} \mathrm{H}$ and $\delta^{18} \mathrm{O}$ values in comparison to modern recharge of meteoric origin. b Durov plot displaying the major ion composition of groundwater from the LRE. The ionic composition of LRE palaeo groundwater is $\mathrm{Na}-\mathrm{Cl}-\left(\mathrm{HCO}_{3}\right)$ dominated with $\mathrm{Cl}^{-}$concentration up to $2,460 \mathrm{mg} \mathrm{L}^{-1}$. The Durov plot identifies processes such as cation exchange as well as graphically

could provide the source of the $\mathrm{H}^{+}$ions, but it is more likely that the source of $\mathrm{H}^{+}$ions originates in the production of $\mathrm{CO}_{2}$ in the subsurface because the Brühl groundwater samples are known to have high dissolved $\mathrm{CO}_{2}$ concentrations up to $1,125 \mathrm{mg} \mathrm{L}^{-1}$. Coalification of lignite is a possible source of $\mathrm{CO}_{2}$ which would in turn generate the necessary concentration of $\mathrm{H}^{+}$ions to account for the observed trend of low $\mathrm{Ca}^{2+}$ and relatively high $\mathrm{HCO}_{3}{ }^{-}$ displayed by the palaeo groundwater. The chemical halfreaction involving the diagenesis of lignite that produces $\mathrm{CO}_{2}$ is given by the following equation:

$\mathrm{C}_{n} \mathrm{H}_{2} \mathrm{O} \rightarrow \frac{n}{2} \mathrm{CO}_{2(\mathrm{~g})}+\frac{1}{2} \mathrm{C}_{n} \mathrm{H}_{2 n+2}$

Under anaerobic groundwater conditions, the oxidation of organic matter is possibly achieved via $\mathrm{SO}_{4}{ }^{2-}$ reduction. illustrating subtle differences in the hydrochemical composition of modern groundwater recharge. c Cross plot of $\mathrm{HCO}_{3}{ }^{-}+\mathrm{SO}_{4}{ }^{2-}$ against $\mathrm{Ca}^{2+}$. Palaeo groundwater exhibits an anomalous hydrochemical evolution with low $\mathrm{Ca}^{2+}$ and relatively high $\mathrm{HCO}_{3}{ }^{-}$concentrations that require a high production rate of $\mathrm{H}^{+}$ions in the aquifer. Processes such as sulphate reduction can also cause deviations from the 1:1 ratio mixing line

Measured concentrations of dissolved noble gases ( $\mathrm{Ne}, \mathrm{Ar}$, $\mathrm{Kr}$ and $\mathrm{Xe}$ ) were interpreted using NOBLE90 (AeschbachHertig et al. 2000; Peeters et al. 2003) in terms of noble gas temperatures (NGTs) and excess air (see Table 1). Comparing NGTs and excess air concentrations to hydrochemical and stable isotope data, it is possible to identify two groundwater types in terms of the long-term recharge history. Modern groundwater recharge is characterised as having lower excess air concentrations in the range of $5-36 \% \Delta \mathrm{Ne}$ and an average NGT of $12.5 \pm 1.3{ }^{\circ} \mathrm{C}$. Palaeo groundwater generally exhibits higher excess air concentrations from $32-75 \% \Delta \mathrm{Ne}$ and a lower NGT of $5.6 \pm 1.7{ }^{\circ} \mathrm{C}$. Erftverband weather station data show that the current weighted-mean-annual surface air temperature for the region is $10.8^{\circ} \mathrm{C}$, which is $1.7^{\circ} \mathrm{C}$ lower than the calculated mean NGT for modern groundwater. Although the uncertainty limits for the calculated NGT could explain 
most of this difference, it is possible that NOBLE90 does not adequately describe all the mechanisms that control noble gas concentrations at the water table in the LRE. The modelled NGT of the palaeo groundwater is not inconsistent with the findings of Andrews and Lee (1979) and Stute et al. (1995) that show palaeo groundwater displaying a temperature decrease of $5-7^{\circ} \mathrm{C}$, although some studies report a smaller temperature decrease in the range of $2-3{ }^{\circ} \mathrm{C}$ between Holocene and Pleistocene recharge (e.g. Osenbrück et al. 1993). However, although much of the data indicate late Pleistocene recharge of meteoric origin in the Brühl region, helium data (Fig. 3) suggest a much longer residence time. A groundwater residence time can be estimated for the Brühl groundwater samples using ${ }^{4} \mathrm{He}$ concentration data. In this study, a terrigenic-diffusive-flux-rate estimate of $4 \times 10^{9}$ atoms ${ }^{4} \mathrm{He} \mathrm{m}^{-2} \mathrm{~s}^{-1}$ was taken from the literature presented by Torgersen (2010) for a similar hydrogeological setting to estimate helium input to the deep groundwater system (prior to recent upward movement along faults), but generally many values used in our calculation were under-constrained. Recent terrigenic helium inputs to the shallow aquifer system are assumed to be negligible; however, a ${ }^{4} \mathrm{He}$ age for 'old' groundwater at shallow depth in the Brühl region of approximately $10^{7}$ years was estimated, which is, thus, more ancient than Quaternary palaeo groundwater. In situ production of helium cannot account for the observed ${ }^{4} \mathrm{He}$ concentrations, so a terrigenic flux must be invoked. Further analytical work to determine the ${ }^{3} \mathrm{He} /{ }^{4} \mathrm{He}$ ratio of Brühl groundwater would be useful to identify the relative magmatic contribution.

A conceptual hydrogeochemical model (Fig. 4) elucidates the observed occurrence of palaeo groundwater with a deep crustal component at very shallow depth in the Brühl region. In situ ${ }^{4} \mathrm{He}$ production derived from $\alpha$-decay of U-Th series elements in the subsurface as well as a significant external flux of helium are necessary to account for the observed helium concentrations. Hydrochemical analysis indicates that $\mathrm{Na}^{+}$ and $\mathrm{Cl}^{-}$are dominant ions in the palaeo groundwater and that the hydrochemical evolution involved very high $P_{\mathrm{CO} 2}$ conditions and a significant subsurface source of $\mathrm{H}^{+}$ions. The occurrence of deep crustal fluids in shallow aquifers is associated with preferential sub-vertical flow along faults in the LRE. Geochemical and temporal hydraulic head data suggest that the groundwater originates from depth and flows upwards within the fault core material. Conduit flow associated with the Bornheim fault is possibly linked to historic groundwater abstraction in the region. At the location of the Bornheim fault, no thermal anomaly is observed, suggesting that either the flux of upwelling fluid along the fault zone is not vigorous enough to create such a thermal anomaly, or that the plume of fluid observed was emplaced during an episode of enhanced fluid flow caused by groundwater abstraction. A shallow source of helium from U-Th rich lignite deposits could explain the decoupling of helium and heat, but excess helium is absent from groundwater sampled at all other observation boreholes situated near lignite seams, and additional data such as hydrochemistry, water isotopes and ${ }^{14} \mathrm{C}$-dating all support the notion of deep fluid migration from depth to shallow aquifer units.

It is hypothesised that the emplacement of deep fluids at shallow depth occurred during the active dewatering of nearby lignite mines and that conduit flow from depth is either reduced or not occurring at present along the Bornheim fault. The emplaced anomalous fluids also appear to be slow to disperse, perhaps due to the small hydraulic head gradients that currently exist in the shallow aquifers of the Brühl region.

The locations of three observation boreholes situated in the Brühl region are illustrated in Fig. 4 with observation boreholes $352721 / 2$ and 957982 in very close proximity to the Bornheim fault and 958062/3 located slightly further west of the Bornheim fault. The direction of groundwater flow is currently from southwest to northeast in the shallow aquifer system. Observation borehole 958063 yields the highest concentration of dissolved helium and the most $\delta^{18} \mathrm{O}$-depleted water, and is therefore assumed to represent the end-member

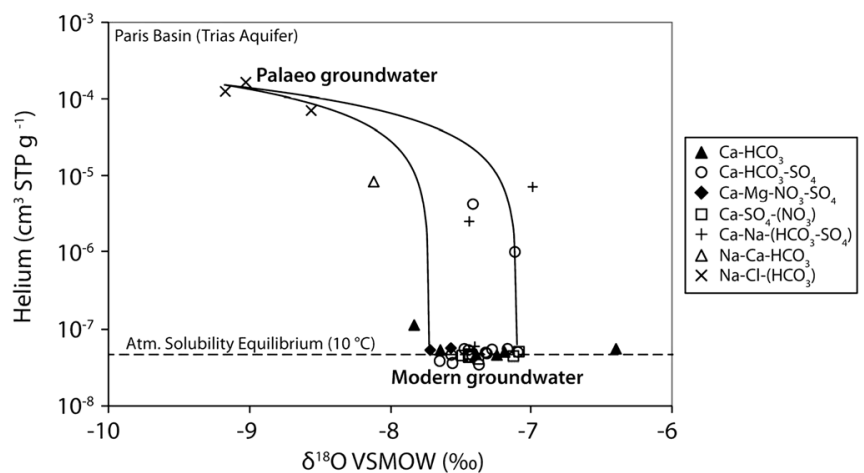

Fig. 3 Cross plot of helium concentration against $\delta^{18} \mathrm{O}$. The solid lines represent a binary mixing envelope between modern groundwater recharge with a range of $\delta^{18} \mathrm{O}$ values and palaeo groundwater. The horizontal dashed line indicates the expected helium concentration due to solubility equilibrium with the atmosphere at $10^{\circ} \mathrm{C}$. Fluids at a depth of $\sim 1,200 \mathrm{~m}$ in the Trias aquifer of the Paris Basin display $\delta^{18} \mathrm{O}$ and helium values (data fall in the shaded area, from Marty et al. 2003) that are similar to the palaeo groundwater observed at very shallow $(<100 \mathrm{~m})$ depth in the Brühl region of the LRE 

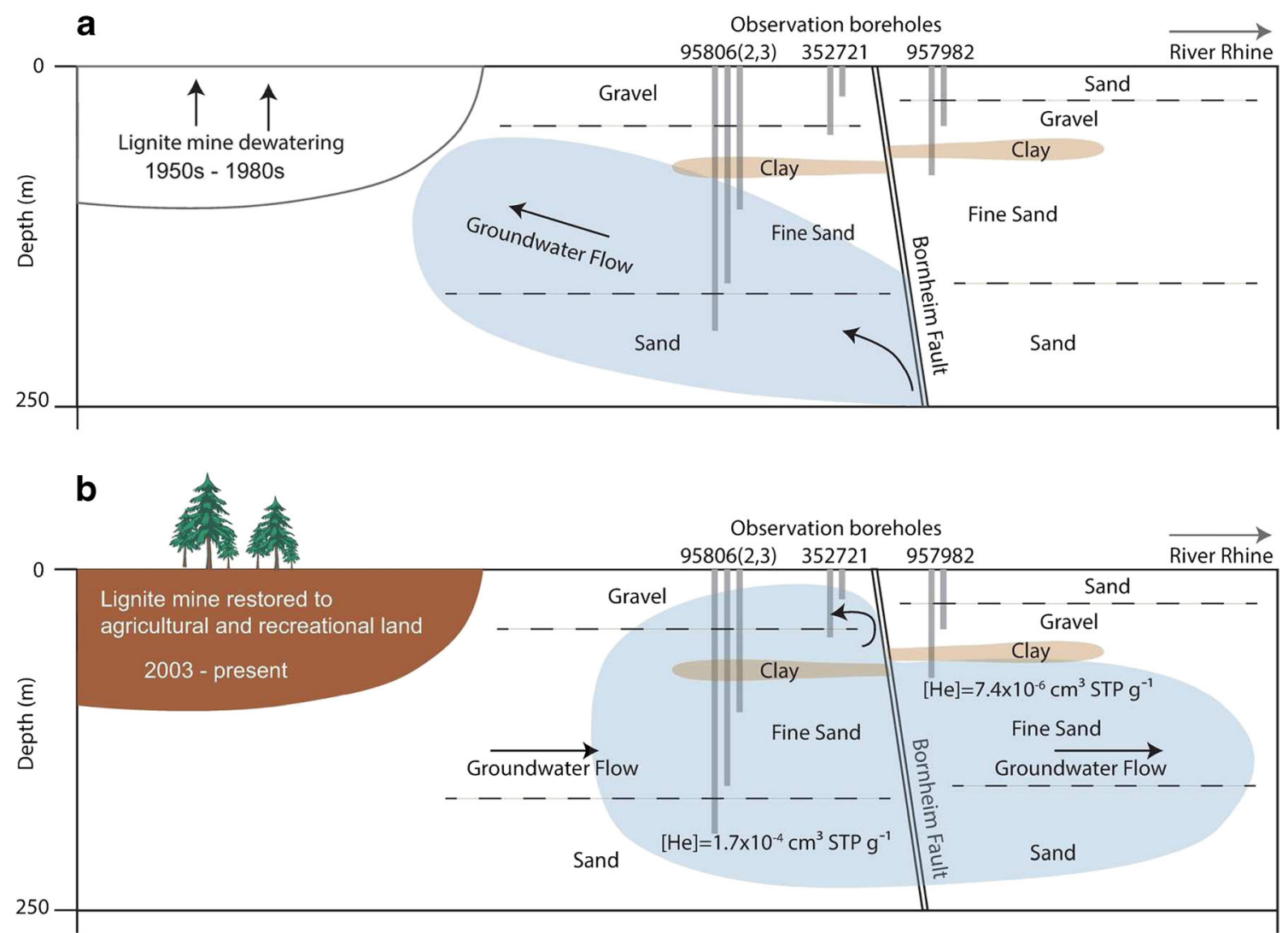

Fig. 4 Conceptual hydrochemical model illustrated by a cross section of the Bornheim fault indicating sub-vertical flow of helium enriched fluid from depth along the fault during periods of lignite mine dewatering (a) and subsequent dispersal following mine restoration (b) represented by the blue-coloured plume. The cross section illustrates the groundwater flow dynamics in the shallow aquifer system of the Brühl region. The deeper $(>250 \mathrm{~m})$ aquifer system is currently influenced by dewatering of the Hambach mine further to the northwest but is effectively isolated from the shallow aquifer system by a very thick confining layer of clay

\section{Conclusions}

Palaeo groundwater with a deep crustal signature is potentially widely distributed at depth within the LRE aquifer system, but only observed at shallow depth in a few areas close to fault zones. It is possible that point source emanations similar to those described here occur frequently in close proximity to faults, but remain undetected due to the often sparse distribution of observation boreholes near faults. The influence of groundwater abstraction on sub-vertical conduit flow along faults remains uncertain. Similar crustal fluids have been reported at depth in numerous aquifer systems worldwide (e.g. Marty et al. 2003) but rarely at near-surface depths $(<100 \mathrm{~m})$.

It is concluded that this study provides support for a conceptual model of fault zone hydrogeology in unconsolidated sedimentary aquifers in which faults can operate as both barriers for lateral fluid flow, while along the fault, fluid flow can potentially be enhanced. How exactly fluid flow patterns around fault zones develop depends on the way hydraulic stress is imposed onto the groundwater system, for example by groundwater abstraction, $\mathrm{CO}_{2}$ injection or shale gas development. In this particular study, it is demonstrated that time- 
variant boundary conditions as a result of historical trends in the pumping regime in the study area, have led to geochemical patterns that demonstrate leakage of deep fluids into shallow aquifers via fault zones. The observations thus provide a perspective on how fault zones can behave as hydrogeological pathways between shallow and deep systems as triggered by human activity at shallow depth (e.g. $<100 \mathrm{~m}$ ), but similar effects could occur via other hydrogeological mechanisms that create hydraulic gradients near fault zones (e.g. fluid injection at depth).

Acknowledgements This research was funded by a United Kingdom Natural Environment Research Council (NERC) Studentship (NER/S/A/ 2006/14113) awarded to Lee P. Gumm. Thanks go to Dr. Peter Sauer for ${ }^{14} \mathrm{C}$ dating (US National Science Foundation grant NSF-EAR 0609809). Special thanks also go to the technical staff at the Erftverband in Bergheim for providing field support and hydrochemical analyses.

Open Access This article is distributed under the terms of the Creative Commons Attribution 4.0 International License (http:// creativecommons.org/licenses/by/4.0/), which permits unrestricted use, distribution, and reproduction in any medium, provided you give appropriate credit to the original author(s) and the source, provide a link to the Creative Commons license, and indicate if changes were made.

\section{References}

Aeschbach-Hertig W, Peeters F, Beyerle U, Kipfer R (2000) Palaeotemperature reconstruction from noble gases in ground water taking into account equilibration with entrapped air. Nature 405: $1040-1044$

Andrews JN, Lee DJ (1979) Inert gases in groundwater from the Bunter Sandstone of England as indicators of age and palaeoclimatic trends. J Hydrol 41(3-4):233-252

Appelo CAJ, Postma D (2005) Geochemistry, groundwater and pollution, 2nd edn. CRC, Amsterdam

Ballentine CJ, Burnard PG (2002) Production, release and transport of noble gases in the continental crust. Rev Mineral Geochem 47(1): 481-538

Ballentine CJ, Burgess R, Marty B (2002) Tracing fluid origin, transport and interaction in the crust. Rev Mineral Geochem 47(1):539-614

Bense VF, Person MA (2006) Faults as conduit-barrier systems to fluid flow in siliciclastic sedimentary aquifers. Water Resour Res 42(5): W05421

Bense VF, van Balen RT (2004) The impact of clay-smearing and fault relay on groundwater flow patterns in the Lower Rhine Embayment. Basin Res 16:397-411

Bense VF, van Balen RT, De Vries JJ (2003) The impact of faults on the hydrogeological conditions in the Roer Valley Rift System: an overview. Geol Mijnb 82(1):41-54

Bense VF, Person MA, Chaudhary K, You Y, Cremer N, Simon S (2008) Thermal anomalies indicate preferential flow along faults in unconsolidated sedimentary aquifers. Geophys Res Lett 35(24):L24406

Bense VF, Gleeson T, Loveless SE, Bour O (2013) Fault zone hydrogeology. Earth-Sci Rev. doi:10.1016/j.earscirev.2013.09.008

Bethke CM, Zhao X, Torgersen T (1999) Groundwater flow and the ${ }^{4} \mathrm{He}$ distribution in the Great Artesian Basin of Australia. J Geophys Res 104(B6):12999-13011

Beyerle U, Aeschbach-Hertig W, Imboden DM, Baur H, Graf T, Kipfer R (2000) A mass spectrometric system for the analysis of noble gases and tritium from water samples. Environ Sci Technol 34(10):20422050

Bickle M, Chadwick A, Huppert HE, Hallworth M, Lyle S (2007) Modelling carbon dioxide accumulation at Sleipner: implications for underground carbon storage. Earth Planet Sci Lett 255(1-2): $164-176$

Boenigk W (2002) The Pleistocene drainage pattern in the Lower Rhine Basin. Geol Mijnb 81(2):201-209

Cassiat C, Gleeson T, Lefevre R, McKenzie J (2013) Hydraulic fracturing in faulted sedimentary basins: numerical simulation of potential contamination of shallow aquifers over long time scales. Water Resour Res 49:8310-8327

Castro MC (2004) Helium sources in passive margin aquifers: new evidence for a significant mantle ${ }^{3} \mathrm{He}$ source in aquifers with unexpectedly low in situ ${ }^{3} \mathrm{He} /{ }^{4} \mathrm{He}$ production. Earth Planet Sci Lett 222(3-4): 897-913

Castro MC, Jambon A, de Marsily G, Schlosser P (1998) Noble gases as natural tracers of water circulation in the Paris Basin 1: measurements and discussion of their origin and mechanisms of vertical transport in the basin. Water Resour Res 34:2443-2466

Castro MC, Stute M, Schlosser P (2000) Comparison of ${ }^{4} \mathrm{He}$ ages and ${ }^{14} \mathrm{C}$ ages in simple aquifer systems: implications for groundwater flow and chronologies. Appl Geochem 15(8):1137-1167

Chan MA, Parry WT, Bowman JR (2000) Diagenetic hematite and manganese oxides and fault-related fluid flow in Jurassic Sandstones, southeastern Utah. AAPG Bull 84(9):1281-1310

Dewhurst DN, Jones RM (2003) Influence of physical and diagenetic processes on fault geomechanics and reactivation. J Geochem Explor 78-79:153-157

Dublyansky YV, Spötl C (2010) Evidence for a hypogene paleohydrogeological event at the prospective nuclear waste disposal site Yucca Mountain, Nevada, USA, revealed by the isotope composition of fluid-inclusion water. Earth Planet Sci Lett 289:583-594

Egholm DL, Clausen OR, Sandiford M, Kristensen MB, Korstgård JA (2008) The mechanics of clay smearing along faults. Geology 36: 787-790

Flint AL, Flint LE, Kwicklis EM, Bodvarsson GS, Fabryka-Martin JM (2001) Hydrology of Yucca Mountain, Nevada. Rev Geophys 39(4): $447-470$

Fulljames JR, Zijerveld LJJ, Franssen RCMW (1997) Fault seal processes: systematic analysis of fault seals over geological and production time scales. NPF Spec Publ 7:51-59

Gardner WP, Harrington GA, Smerdon BD (2012) Using excess ${ }^{4} \mathrm{He}$ to quantify variability in aquitard leakage. J Hydrol 468-469:63-75

Geluk MC, Duin EJT, Dusar M, Rijkers RHB, van den Berg MW, van Rooijen P (1994) Stratigraphy and tectonics of the Roer Valley Graben. Geol Mijnb 73:129-141

Gilfillan SMV, Lollar BS, Holland G, Blagburn D, Stevens S, Schoell M, Cassidy M, Ding Z, Zhou Z, Lacrampe-Couloume G, Ballentine CJ (2009) Solubility trapping in formation water as dominant $\mathrm{CO}_{2}$ sink in natural gas fields. Nature 458(7238):614-618

Griesshaber E, O’Nions RK, Oxburgh ER (1992) Helium and carbon isotope systematics in crustal fluids from the Eifel, the Rhine Graben and Black Forest, F.R.G. Chem Geol 99(4):213-235

Hager H (1993) The origin of the Tertiary lignite deposits in the Lower Rhine region, Germany. Int J Coal Geol 23(1-4):251-262

IAEA/WMO (2006) Global network of isotopes in precipitation: the GNIP database. Available at: http://www.iaea.org/water. Accessed 7 September 2015

Kemna HA (2008) A revised stratigraphy for the Pliocene and lower Pleistocene deposits of the Lower Rhine Embayment. Neth J Geosci 87(1):91-105

Kipfer R, Aeschbach-Hertig W, Peeters F, Stute M (2002) Noble gases in lakes and ground waters. Rev Mineral Geochem 47(1):615-700 
Kulongoski JT, Hilton DR, Izbicki JA (2003) Helium isotope studies in the Mojave Desert, California: implications for groundwater chronology and regional seismicity. Chem Geol 202:95-113

Kulongoski JT, Hilton DR, Izbicki JA (2005) Source and movement of helium in the eastern Morongo groundwater Basin: the influence of regional tectonics on crustal and mantle helium fluxes. Geochim Cosmochim Acta 69(15):3857-3872

Lavastre V, Salle CLGL, Michelot J-L, Giannesini S, Benedetti L, Lancelot J, Lavielle B, Massault M, Thomas B, Gilabert E, Bourlès D, Clauer N, Agrinier P (2010) Establishing constraints on groundwater ages with ${ }^{36} \mathrm{Cl},{ }^{14} \mathrm{C},{ }^{3} \mathrm{H}$, and noble gases: a case study in the eastern Paris Basin, France. Appl Geochem 25(1):123142

Lehner FK, Pilaar WF (1997) On a mechanism of clay smear emplacement in synsedimentary normal faults. In: Møller-Pedersen P, Koestler AG (eds) Hydrocarbon seals: importance for exploration and production. NPF Spec. Pub. 7, Elsevier, Amsterdam, pp 39-50

Lippmann J, Stute M, Torgersen T, Moser DP, Hall JA, Lin L, Borcsik M, Bellamy RES, Onstott TC (2003) Dating ultra-deep mine waters with noble gases and ${ }^{36} \mathrm{Cl}$, Witwatersrand Basin, South Africa. Geochim Cosmochim Acta 67(23):4597-4619

Lippmann J, Erzinger J, Zimmer M, Schloemer S, Eichinger L, Faber E (2005) On the geochemistry of gases and noble gas isotopes (including ${ }^{222} \mathrm{Rn}$ ) in deep crustal fluids: the $4000 \mathrm{~m}$ KTB-pilot hole fluid production test 2002-03. Geofluids 5(1):52-66

Lippmann-Pipke J, Sherwood Lollar B, Niedermann S, Stroncik NA, Naumann R, van Heerden E, Onstott TC (2011) Neon identifies two billion year old fluid component in Kaapvaal Craton. Chem Geol 283(3-4):287-296

Ma L, Castro MC, Hall CM, Walter LM (2005) Cross-formational flow and salinity sources inferred from a combined study of helium concentrations, isotopic ratios, and major elements in the Marshall aquifer, southern Michigan. Geochem Geophys Geosyst 6:Q10004

Mailloux BJ, Person M, Kelley S, Dunbar N, Cather S, Strayer L, Hudleston P (1999) Tectonic controls on the hydrogeology of the Rio Grande Rift, New Mexico. Water Resour Res 35(9):2641-2659

Marty B, Torgersen T, Meynier V, O’Nions RK, de Marsily G (1993) Helium isotope fluxes and groundwater ages in the Dogger aquifer, Paris Basin. Water Resour Res 29:1025-1035

Marty B, Dewonck S, France-Lanord C (2003) Geochemical evidence for efficient aquifer isolation over geological timeframes. Nature 425(6953):55-58

Mayer A, May W, Lukkarila C, Diehl J (2007) Estimation of fault zone conductance by calibration of a regional groundwater flow model: Desert Hot Springs, California. Hydrogeol J 15:1093-1106

Osenbrück K, Weise SM, Zuber A, Grabczak J, Ciezkowski W (1993) Noble gas temperatures and ages of some glacial and buried brine waters in Poland. In: Isotope techniques in the study of past and current environmental changes in the hydrosphere and the atmosphere. IAEA, Vienna, pp 319-336

Oxburgh ER, O’Nions RK, Hill RI (1986) Helium isotopes in sedimentary basins. Nature 324(6098):632-635

Peeters F, Beyerle U, Aeschbach-Hertig W, Holocher J, Brennwald MS, Kipfer R (2003) Improving noble gas based paleoclimate reconstruction and groundwater dating using ${ }^{20} \mathrm{Ne} /{ }^{22} \mathrm{Ne}$ ratios. Geochim Cosmochim Acta 67(4):587-600

Poole JC, McNeill GW, Langman SR, Dennis F (1997) Analysis of noble gases in water using a quadrupole mass spectrometer in static mode. Appl Geochem 12(6):707-714

Rawling GC, Goodwin LB, Wilson JL (2001) Internal architecture, permeability structure, and hydrologic significance of contrasting faultzone types. Geology 29(1):43-46

Roberts SJ, Nunn JA, Cathles L, Cipriani F (1996) Expulsion of abnormally pressured fluids along faults. J Geophys Res 101(B12): $28231-28252$
Sano Y, Wakita H, Huang CW (1986) Helium flux in a continental land area estimated from ${ }^{3} \mathrm{He} /{ }^{4} \mathrm{He}$ ratio in northern Taiwan. Nature 323(6083):55-57

Schäfer A, Hilger D, Gross G, von der Hocht F (1996) Cyclic sedimentation in Tertiary Lower-Rhine Basin (Germany): the 'Liegendrucken' of the brown-coal open-cast Fortuna mine. Sediment Geol 103(3-4):229-247

Schäfer A, Utescher T, Klett M, Valdivia-Manchego M (2005) The Cenozoic Lower Rhine Basin: rifting, sedimentation, and cyclic stratigraphy. Int J Earth Sci 94(4):621-639

Schenk V (1981) Die Tiefenlage der Salzwasser-Süßwassergrenze in der südlichen Niederrheinischen Bucht [The depth of the interface between saline and fresh water in the Lower Rhine Embayment, Germany]. Z Dt Geol Ges 132:613-621

Schenk V (1982) Hydrogeologie und Grundwasserbeschaffenheit im Raume Brühl-Wesseling [Hydrogeology and groundwater quality in the the Bruhl-Wesseling region]. Grosser Erftverband, Bergheim, Germany, $27 \mathrm{pp}$

Shipton ZK, Evans JP, Kirschner D, Kolesar PT, Williams AP, Heath J (2004) Analysis of leakage through 'low-peameability' faults from natural reservoirs in the Colorado Plateau, east-central Utah. In: Baines SJ, Worden RH (eds) Geological storage of carbon dioxide. Geol Soc Lond Spec Publ 233:43-58

Solomon DK, Hunt A, Poreda RJ (1996) Source of radiogenic helium-4 in shallow aquifers: implications for dating young groundwater. Water Resour Res 32(6): 1805-1813

Stute M, Sonntag C, Deak J, Schlosser P (1992) Helium in deep circulating groundwater in the Great Hungarian Plain: flow dynamics and crustal and mantle helium fluxes. Geochim Cosmochim Acta 56(5): 2051-2067

Stute M, Forster M, Frischkorn H, Serejo A, Clark JF, Schlosser P, Broecker WS, Bonani G (1995) Cooling of tropical Brazil $\left(5^{\circ} \mathrm{C}\right)$ during the last glacial maximum. Science 269(5222):379-383

Torgersen T (2010) Continental degassing flux of ${ }^{4} \mathrm{He}$ and its variability. Geochem Geophys Geosyst 11(6):Q06002

Torgersen T, Clarke WB (1985) Helium accumulation in groundwater, I: an evaluation of sources and the continental flux of crustal ${ }^{4} \mathrm{He}$ in the Great Artesian Basin, Australia. Geochim Cosmochim Acta 49(5): $1211-1218$

Torgersen T, Clarke WB (1987) Helium accumulation in groundwater, III: limits on helium transfer across the mantle-crust boundary beneath Australia and the magnitude of mantle degassing. Earth Planet Sci Lett 84(2-3):345-355

Torgersen T, Habermehl MA, Clarke WB (1992) Crustal helium fluxes and heat flow in the Great Artesian Basin, Australia. Chem Geol 102(1-4):139-152

Vaikmäe R, Vallner L, Loosli HH, Blaser PC, Juillard-Tardent M (2001) Palaeogroundwater of glacial origin in the Cambrian-Vendian aquifer of northern Estonia. Geol Soc Lond Spec Publ 189(1):17-27

Wallbraun A (1992) Einfluß der Schollenrandstörungen in der Niederrheinischen Bucht auf den Grundwasserabfluß [Impact of block-bounding faults in groundwater flow in the Lower Rhine Emabyment, Germany]. PhD Thesis, Rheinisch-Westfälischen Technischen Hochschule, Aachen, Germany

Wiersberg T, Erzinger J (2011) Chemical and isotope compositions of drilling mud gas from the San Andreas Fault Observatory at Depth (SAFOD) borehole: implications on gas migration and the permeability structure of the San Andreas Fault. Chem Geol 284:148-159

Wiprut D, Zoback MD (2000) Fault reactivation and fluid flow along a previously dormant normal fault in the northern North Sea. Geology 28(7):595-598

Zhou Z, Ballentine CJ (2006) ${ }^{4} \mathrm{He}$ dating of groundwater associated with hydrocarbon reservoirs. Chem Geol 226(3-4):309-327

Ziegler PA (1994) Cenozoic rift system of Western and Central Europe: an overview. Geol Mijnb 73:99-127 